\title{
KANDUNGAN PROTEIN DAN KALSIUM PADA BISKUIT FORMULA TEMPE DENGAN PENAMBAHAN TEPUNG DAUN KELOR (MORINGA OLEIFERA)
}

\author{
Tri Suhartini ${ }^{1}$, Zakaria $^{2}$, Asmarudin Pakhri ${ }^{2}$, Mustamin $^{2}$ \\ ${ }^{1)}$ Alumni Prodi D-IV, Jurusan Gizi, Politeknik Kesehatan Kemenkes, Makassar \\ ${ }^{2}$ Jurusan Gizi, Politeknik Kesehatan Kemenkes, Makassar
}

Korespondensi, E-Mail : trisuhartini@poltekkes-mks.ac.id

\begin{abstract}
The results of the research on tempe biscuit with the substitution of moringa flour as MP-ASI did not reveal the content of protein and calcium which is a nutrient Which is important to know as fast food. This study aims to determine the content of protein and calcium in tempe biscuit formula with kelor leaf flour substitution. This research uses laboratory. Samples analyzed were 2 samples with no substitution of 0\% Moringa flour (control) and samples with Moringa flour substitution 9\% (13.5 g) based on consumer acceptance. Aanalysis of proteins by khjedal method and mineral by atomic analysis spektrofothometer (AAS). The results showed that the content of protein and calcium biscuit of tempe formula with the substitution of maize flour 9\% $(13.5 \mathrm{~g})$ respectively by $14.9 \%$ and $38.3 \mathrm{mg}$, Greater than non-substitution of maize leaf powder respectively $12.6 \%$ and $21.4 \mathrm{~g}$. It was concluded that the content of protein and calcium biscuit with the substitution of moringa flour is higher than that without the substitution of moringa flour. Further research on the formulation of complementari of food for breast milk is required to balance the nutritional value in accordance with the needs of infants 6-24 months.
\end{abstract}

Keywords : Biscuits, Calcium Content, Protein Content

\section{PENDAHULUAN}

Usia 6 bulan hingga 24 bulan merupakan masa yang sangat penting untuk pertumbuhan dan perkembangan anak, oleh karena itu tenaga kesehatan mempunyai peranan penting dalam membantu keluarga dalam mencapai tumbuh kembang yang optimal. Makanan Pendamping ASI (MP-ASI) adalah makanan atau minuman yang mengandung zat gizi dan diberikan kepada bayi atau anak usia 6-24 bulan guna memenuhi kebutuhan gizi selain dari ASI (Depkes RI, 2006).
Protein adalah sebagian dari semua sel hidup dan merupakan bagian terbesar tubuh sesudah air. Seperlima bagian tubuh adalah protein, separuhnya ada di dalam otot, seperlima didalam tulang dan tulang rawan, sepersepuluh didalam kulit, dan selebihnya di dalam jaringan lain dan cairan tubuh. Semua enzim, berbagai hormon, pengangkut zat-zat gizi dan darah, matriks intraseluler dan sebagainya adalah protein. Protein mempunyai fungsi khas yang tidak dapat digantikan oleh zat gizi lain, yaitu membangun serta memelihara sel-sel dan jaringan tubuh (Almatsier, 2010). 
Kalsium merupakan mineral yang paling banyak terdapat di dalam tubuh, yaitu $1,5-2 \%$ dari berat bada orang dewasa atau kurang lebih sebanyak $1 \mathrm{~kg}$. Kalsium paling banyak terdapat dalam jaringan keras, yaitu tulang dan gigi. Di dalam cairan ekstraseluler dan intraseluler kalsium berperan penting dalam mengatur fungsi sel, seperti untuk transmisi saraf, kontraks otot, penggumpalan darah dan mencaga permeabilitas membrane sel, dan mengatur pekerjaan hormon-hormon serta faktor pertumbuhan.

Tepung formula tempe merupakan makanan terolah bahan utama tempe yang kemudian diformulasikan dengan bahan pendukung lain, dirancang sebagai bahan makanan tambahan untuk mengatasi gangguan pencernaan (diare) dan efektif untuk memperbaiki status penderita gizi kurang, bahkan menghentikan infeksi saluran cerna anak pada usia 6-24 bulan.

Daun kelor memiliki potensi sumber utama beberapa zat gizi dan elemen therapeutic, termasuk antibiotik, dan memacu sistem imun. Daun kelor memiliki kandungan protein, vitamin dan mineral tinggi yang memiliki potensi terapi dan makanan tambahan untuk anak-anak yang kekurangan gizi. Penambahan daun kelor pada makanan harian anak-anak mampu melakukan recovery secara cepat karena mengandung 40 zat gizi esensial (Fuglie at all, dalam Zakaria, dkk, 2013).

Hasil Penelitian (Zakaria, dkk, 2012) menunjukkan bahwa penambahan tepung daun kelor 3-5 gram sehari pada makanan anak balita gizi kurang dapat meningkatkan nafsu makan anak dan berat badan anak pada umumnya naik setiap bulan. Namun dalam pemberian tepung daun kelor tersebut kurang praktis, oleh karena pemberiannya diatur oleh ibu balita sendiri dan takarannya tidak pasti, tergantung kehendak ibu dan keinginan anaknya.

Hasil Riskesdas 2013, menunjukkan bahwa terdapat $13,9 \%$ anak balita yang menderita gizi kurang dan 5,7 $\%$ penderita gizi buruk. Sementara itu prevalensi balita yang pendek terdapat 19,2 $\%$ dan sangat kurus terdapat 5,3\%. Menurut laporan Dinas Kesehatan Kota Makassar Tahun 2014 tercatat bahwa jumlah status gizi balita menurut $\mathrm{BB} / \mathrm{U}$ masing-masing gizi buruk 2,3\% dan gizi kurang $8,35 \%$ ).

Berdasarkan masalah tersebut di atas, maka peneliti tertarik membuat biskuit dengan formulasi bahan dasar formula tempe dengan penambahan tepung daun kelor.

\section{METODE PENELITIAN}

Jenis penelitian ini adalah penelitian pra eksperimental dengan pendakatan formulasi yang analisis di Laboratorium. Penelitian ini bertujuan untuk mengetahui kandungan protein dan kalsium pada biskuit formula tempe dengan penambahan tepung daun kelor.

Sampel yang dianalisis adalah biskuit formula tempe dengan penambahan tepung daun kelor $9 \% \quad(13,5 \mathrm{~g})$ berdasarkan hasil uji daya terima konsumen yang disukai. Kandungan protein dianalisis menggunakan metode kjeldahl dan kandungan kalsium mengunakan alat Atonomic Absorption Spectrophotometer (AAS).

\section{HASIL}

Hasil analisa kandungan protein dan kalsium pada biskuit formula tempe dengan penambahan tepung daun kelor dapat dilihat pada tabel berikut: 
Tabel 1

Kandungan Protein Biskuit Formula Tempe dengan

Penambahan Tepung Daun Kelor dalam 100 g

\begin{tabular}{llclcc}
\hline \hline No. & \multicolumn{2}{c}{ Jenis Sampel } & Protein $(\mathrm{g})$ & Kalsium $(\mathrm{mg})$ \\
\hline 1. & $\begin{array}{l}\text { Tanpa penambahan tepung } \\
\text { (Control) }\end{array}$ & kelor & 12,6 & 21,4 \\
2. & $\begin{array}{l}\text { Penambahan tepung kelor 9\% } \\
\text { gram) }\end{array}$ & $(13,5$ & 14,9 & 38,3 \\
\hline
\end{tabular}

Tabel 1 menunjukkan bahwa kandungan protein dan kalsium biskuit formula tempe dengan penambahan tepung daun kelor $9 \% \quad(13,5 \mathrm{~g})$ menunjukkan perbedaan sangat jelas dengan biskuit formula tempe tanpa penambahan tepung daun kelor yaitu masing-masing kandungan protein sebesar 14,9 g vs 12,6 g dan kandungan kalsium sebesar $38,3 \mathrm{mg}$ vs $21,4 \mathrm{mg}$.

\section{PEMBAHASAN}

Hasil analisa kandungan protein biskuit formula tempe dengan penambahan tepung daun kelor yang dihasilkan pada penelitian ini yang tanpa penambahan tepung daun kelor 0\% lebih rendah dibanding dengan penambahan tepung daun kelor konsentrasi 9\% (13,5 gram), kandungan protein tersebut meningkat sekitar 18, $2 \%$ (12,6 menjadi 14,9\%). Kandungan protein kedua biskuit berdasarkan uji laboratorium telah melebihi standar syarat mutu biskuit secara umum yang ditetapkan dalam SNI No. 012973-1992 adalah minimum 9\%.

Peningkatan protein disebabkan karena penambahan tepung daun kelor, nilai protein daun kelor dalam 100 gram yaitu $28,25 \%$. Semakin banyak tepung daun kelor yang disuplementasikan atau ditambahkan kedalam biskuit makan kadar protein yang ada pada biskuit menjadi tinggi.

Kelor mengandung 18 asam amino, yaitu 8 jenis asam amino esensial dan 10 jenis asam amino non esensial. Asam amino esensial meliputi isoleusin, leucine, lisin, metionin, phenylalaine, treonin, tryptophan, valin. Asam amino nonesensial meliputi Alanin, Arginine, Asam Aspartat, Sistin, Asam Glutamat, Glycine, Histidin, Serine, Proline, Tryrosine. Kandungan asam amino kelor lebih banyak jika dibandingkan dengan asam amino telur.

Kandungan protein merupakan faktor yang penentu mutu bahan makanan. Semakin tinggi kandungan protein suatu bahan makanan maka kualitas dari bahan makanan tersebut akan semakin tinggi. Selain itu kandungan protein dapat dijadikan sebagai acuan dalam pemilihan bahan makanan terutama untuk mereka yang masih dalam masa pertumbuhan. Suatu produk makanan dapat dijadikan sebagai sumber zat gizi (protein) apabila dapat memenuhi minimal $10 \%$ dari total kebutuhan zat gizi dalam sehari.

Kebutuhan protein meningkat pada masa remaja karena proses pertumbuhan yang sedang terjadi dengan cepat. Kebutuhan protein remaja adalah sebesar $15 \%$ dari dari kebutuhan energi total (Sianturi putuhuru, 2007). Sedangkan kebutuhan protein untuk anak balita $6-24$ bulan adalah $18 \mathrm{gr}$.

Protein mempunyai fungsi khas, yang tidak dapat digantikan oleh zat gizi lain, yaitu membentuk jaringan baru dalam masa pertumbuhan dan perkembangan tubuh, memelihara jaringan tubuh, memperbaiki serta mengganti jaringan yang rusak, atau mati, menyediakan asam amino yang diperlukan untuk membentuk enzim pencernaan dan metabolisme, pembentukan antibodi, mengatur 
keseimbangan air, dan memepertahankan kenetralan asam basa tubuh, karena pentingnya protein bagi tubuh, maka kualitas makanan juga ditentukan oleh kandungan protein dalam bahan makanan tersebut. (Baliwati, dkk,2004).

\section{Kandungan Kalsium pada Biskuit Formula}

Kalsium adalah mineral yang sangat penting bagi tubuh manusia. Fungsi utama kalsium adalah mengisi kepadatan (densitas) tulang. Kalsium juga berperan dalam pembentukan gigi. Kaslium dibutuhkan untuk pembekuan darah, transmisi saraf, stimulasi otot, stabilitas asam basa $(\mathrm{pH})$ darah, dan mempertahankan keseimbangan air. Kalsium juga berperan penting dalam reaksi enzim, tekanan darah,dan mencegah kanker usus besar, sehingga kalsium sangat penting dalam kehidupan dan kesehatan (Wirakusuma, 2010).

Hasil analisa kandungan kalsium biskuit yang dihasilkan pada penelitian ini dengan tanpa penambahan tepung daun kelor $0 \%$ adalah 21,356 mg, sedangkan dengan penambahan tepung daun kelor meningkatkan nilai kalsium biskuit formula tempe dengan penambahan tepung daun kelor 9\% (13,5 g) yaitu 38,297 mg. Pada kedua sampel tersebut hanya menyumbang kalsium sebanyak 10-14\% dalam 100 gram biskuit dari standar MPASI biskuit. Kandungan kalsium pada kedua biskuit tersebut tidak memenuhi standar MP-ASI biskuit yang ditetapkan dalam MENKES 2007 adalah 200-300 mg.

Pada kedua sampel biskuit formula tempe dengan penambahan tepungdaun kelor dapat dijadikan sebagai MP-ASI untuk memenuhu kebutuhan gizi balita pada umur 6-24 bulan. MP-ASI adalah pemberian makanan lain selain ASI sebagai makanan pendamping ASI yang diberikan kepada anak usia 6-24 bulan. MP-ASI yang baik dan tepat adalah MPASI yang dapat memenuhi kebutuhan gizi sehingga anak bisa tumbuh secara optimal. MP-ASI berperan untuk memenuhi kebutuhan gizi selain ASI sehingga proses pertumbuhan fisik, perkembangan dan kecerdasan anak tidak terganggu.

ASI memenuhi seluruh kebutuhan bayi terhadap zat-zat gizi yang dierlukan untuk pertumbuhan dan kesehatan sampai berumur 6 bulan. Menjelang umur 6 bulan bayi tidak lagi mendapat cukup energi dan zat gizi dari ASI. Kebutuhan zat gizi semakin bertambah sesuai dengan peningkatan umur bayi atau anak karena proses tumbuh kembang. ASI hanya memenuhi sekitar 60-70\% kebutuhan gizi bayi setelah usia 6 bulan, sehingga bayi mulai membutuhkan MP-ASI.

Pemberian MP-ASI bermanfaat untuk mencapai pertumbuhan dan perkembangan yang optimal, menghindari terjadinya kekurangan zat gizi baik makro maupun mikro, memelihara kesehatan, mencegah penyakit dan mempercepat pemulihan bila sakit, membantu perkembangan jasmani, rohani, psikomotor, mendidik kebiasaan yang baik tentang makanan dan memperkenalkan bermacam-macam bahan makanan yang sesuai dengan keadaan fisologis bayi.

MP-ASI yang baik adalah makanan yang mengandung sejumlah kalori atau energi (karbohidrat, protein dan lemak), vitamin, mineral dan serat untuk pertumbuhan. Konsumsi pangan anak bayi dan balita harus cukup dan seimbang karena anak balita sedang mengalami proses pertumbuhan dan perkembangan yang pesat. MP-ASI yang baik harus menyediakan energi yang cukup tinggi dan mengandung protein yang bermutu tinggi dengan jumlah yang mencukupi. Hasil penelitian (Sani, 2014) mengatakan bahwa ada hubungan yang bermakna antara asupan protein dengan status perkembangan motorik kasar anak usia 618 bulan 


\section{KESIMPULAN}

1. Kandungan protein biskuit dengan tanpa penambahan tepung daun kelor diperoleh sebesar $12,6 \%$ dan lebih besar dibanding dengan penambahan tepung daun kelor $9 \%(13,5 \mathrm{~g})$ yaitu $14,9 \%$.

2. Kandungan kalsium biskuit dengan tanpa penambahan tepung daun kelor diperoleh sebesar 21,356 mg dan lebih besar dibanding dengan penambahan tepung daun kelor 9\% (13,5 gram) adalah $38,297 \mathrm{mg}$.

\section{SARAN}

Perlu dilakukan penelitian lebih lanjut terhadap formulasi MP-ASI agar nilai gizi seimbang sesuai dengan kebutuhan bayi 6-24 bulan.

\section{DAFTAR PUSTAKA}

Almatsier, S. (2010). Prinsip Dasar Ilmu Gizi. Jakarta: PT Gramedia Pustaka Utama

Baliwati, Yayak F. (2004). Pengantar Pangan Dan Gizi. Jakarta. Penebar Swadaya Beyer. 2004.

Badan Standarisasi Nasional. (1992). SNI 01-2973-1992. Syarat Mutu dan Cara Uji Biskuit. Jakarta. Badan Standarisasi Nasional.

Depkes RI. (2006). Pedoman Umum Pemberian Makanan Pendamping Air Susu Ibu (MP-ASI) Lokal. Jakarta

Fuglie, at all. (2001). The Moringa Tree, A Local Solution to Malnutrition. Dakar Senegal.

Menkes RI. (2007). Spesifikasi Teknis Makanan Pendamping Air Susu Ibu (MPASI). Jakarta

Sani N. (2014). Hubungan Asupan Zat Gizi Terhadap Perkembangan Motorik Kasar Pada Anak Usia 6-18 Bulan Di Kelurahan Pamulang Barat

Wirakusuma, E. S., (2007). Mencegah Osteoporosis Lengkap Dengan 30

\section{Jus}

dan 38 Resep Makanan. Penebar Plus. Jakarta

Zakaria, Tamrin, A, dan Sirajuddin. (2012). Penambahan Tepung Daun Kelor pada Menu Makanan SehariHari Dalam Upaya Penanggulangan Gizi

Kurang pada Anak Balita. Volume XIII (1)

Zakaria., Thamrin, A., Lestari, R.S., dan Hartono, R., (2013). Pemanfaatan Tepung Kelor Dalam Formulasi Pembuatan Makanan Tambahan Untuk Balita Gizi Kurang. Volume $\mathrm{XV}(1)$ 